\title{
An Analysis on Discourse Markers in First 2016 U.S. Presidential Debate
}

\author{
Wang Shu'e, Guo Yanqing \\ Xiamen University Tan Kah Kee College, Xiamen, Fujian, P. R. China \\ cloud9818@xujc.com \\ 254994438@qq.com
}

Keywords: Discourse markers, Presidential debate, Pragmatics.

\begin{abstract}
As a common language phenomenon, discourse markers (DMs) have attracted attentions from numerous linguists since the 1980s. Although researches on DMs are rich and fruitful, relatively few of them study DMs in debates. This paper strives to make an analysis on the pragmatic effects of DMs in debates in the first 2016 U.S. presidential debate, revealing that additional markers such as and and emphatic markers such as very are frequently used and illustrating the functions of these DMs in debates.
\end{abstract}

\section{Introduction}

In daily communication or debates, words like well, and, also, first are frequently used for expressing attitudes or the logical relationship between two utterances. Such words are discourse markers (abbreviated as DMs hereafter). As one of the common language phenomena, DMs have aroused great attention from linguists who study them from various perspectives.

A successful debate requires the speaker to demonstrate his/her viewpoint clearly and attack his/her opponents powerfully and appropriately. Therefore, it goes without saying that the language of expression and argumentation is vital. Playing an indispensable role in linguistics particularly in pragmatics, DMs are frequently used in a bid to enhance the effects of persuasion in debates. DMs are used frequently in the 2016 presidential debates. This paper is to make an analysis on DMs in the first 2016 presidential debate in an attempt to explore their functions.

\section{Literature Review}

Since the 1980s, a confluence of researches in DMs has been conducted by many scholars at home and abroad. The researchers give the definitions of DMs from different angles. (Schiffrin, 1987; Fraser, 1999; Blakemore, 2002; 何自然，1999; 再永平，2000)

Schiffrin, one of the most prominent researchers in studying discourse markers, defines DMs as, "sequentially dependent elements which bracket units of talk." (Schiffrin, 1987: 31)

Fraser defines DMs as a class of lexical expressions drawn primarily from the syntactic class of conjunctions, adverbs, and prepositional phrases. With certain exceptions, they signal a relationship between the interpretation of segment they introduce, S2, and the prior segment, S1. (Fraser, 1999)

He Ziran and Ran Yongping defines DMs as "expressions that show the structure of utterances, coherent and pragmatic relationship in the written as well as oral communication" in a broad sense. (何自然, 苒永平, 2006: 147)

There is also a lack of scholarly census as to precise classification of DMs. Schiffrin (1987) analyzes eleven types of DMs and concludes the main function of them. She divides DMs into 6 classes: 1) marker of information management (such as oh); 2) markers of response (such as well); 3) discourse connectives (such as but, and, or); 4) markers of cause and result (such as because, so); 5) temporal adverbs (such as now, then); 6) information and participation (such as you know, I mean). Phillips classifies DMs in terms of the functions they perform in discourse. She proposes a classification of DMs based on her study of the Japanese language and divides them into two major 
types: 1) logical connectors, which contribute to the coherence of conversation; 2) filler markers, which can be further classified into two sub-categories: filler markers without explicit meaning and filler markers with explicit meaning. The following table is the illustration of her classification. (Chang, 2009)

In Phillips' classification, logical markers refer to several conjunctions or adverbs, which connect oral discourse with logical relations. Filling up markers refer to the markers used for filling up the pause, which have some certain communicative functions and meanings, but do no functions of expressing the specific information content.

There are some researchers who have already investigated DMs in presidential debates. Based on the three presidential debates of 2008, Chang Xinyue demonstrates the functions of DMs from the psychological perspective. (Chang, 2009) Wu Keran studies the DMs in the 2008 first presidential debate under relevance theory, adaptation theory and politeness principle. (Wu, 2010) Shi Lina studies the DMs in the six presidential debates of 2004 and 2008 through adaptation and she discovers the characteristics of DMs and the pragmatic strategies based on the debates. (Shi, 2013)

Nevertheless, there is a paucity of researches weighing on studying DMs in light of 2016 U.S. presidential debates, so are the relations between debaters' speaking styles and their usage of DMs.

\section{Analysis of DMs in the First 2016 Presidential Debate}

\subsection{Introduction of the First 2016 U.S. Presidential Debate}

The material submitted for analysis in this study is collected from the transcription of the video show of the first of 2016 U.S. presidential debate between a candidate from the Democratic Party, Hillary Clinton and a candidate from Republican, Donald Trump. The first presidential debate was held at Hofstra University in Hempstead on September 26, 2016. The 90-minute debate was divided into six segments concerning about three topics: achieving prosperity, America's direction, and securing America. At the beginning of each segment, the same lead-off question will be asked by the judge, Lester Holt, to both candidates, and each of them has two minutes to respond. There was an open discussion from that point to the end of the segment, and the judge gave each of the candidates one minute to comment on the viewpoint of the debaters on the opposite side and state his/her own opinion as a rebuttal.

\subsection{The Classification of DMs used in the First Presidential Debate}

DMs have been pervasively used in the first 2016 U.S. presidential debate. There are 1046 DMs out of total 14627 words, taking a percentage of $7.15 \%$ of the total word number of the debate, which reveals the significance of DMs in the debate. Based on the Phillips' classification of DMs, the DMs used in the chosen material are categorized into fifteen types.

Table 1. Classification of DMs in the First Presidential Debate in 2016

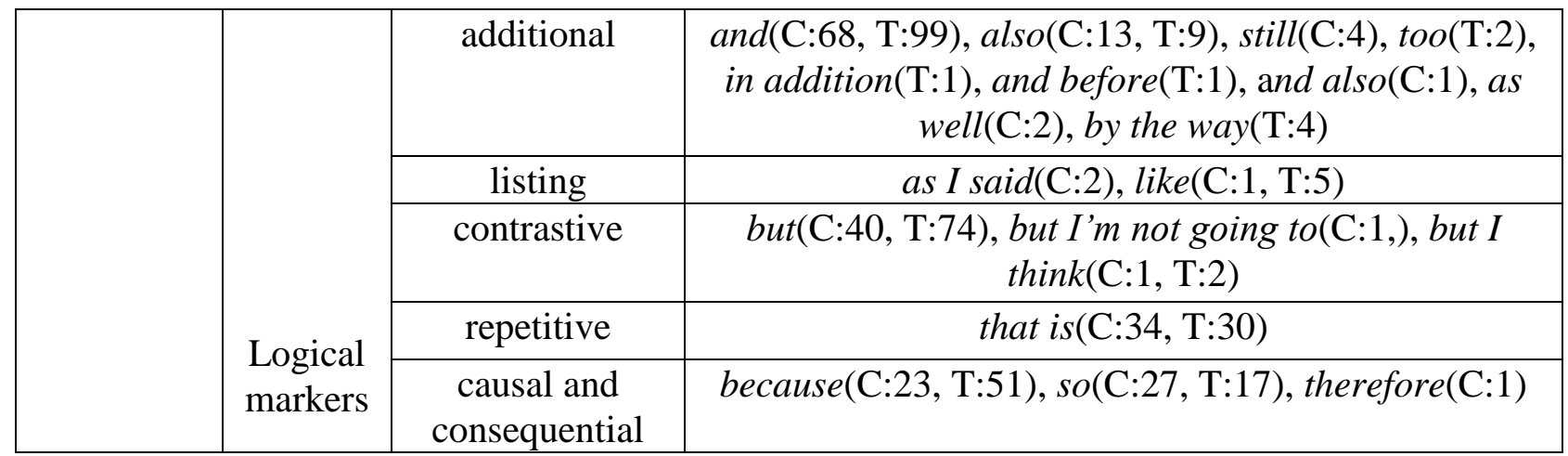




\begin{tabular}{|c|c|c|c|}
\hline \multirow{9}{*}{$\begin{array}{l}\text { Discourse } \\
\text { markers }\end{array}$} & & sequential & $\begin{array}{l}\text { first }(\mathrm{C}: 3, \mathrm{~T}: 1), \text { first of all }(\mathrm{T}: 4), \text { the first thing }(\mathrm{T}: 1) \text {, in } \\
\text { the first place }(\mathrm{C}: 2, \mathrm{~T}: 1), \text { number one }(\mathrm{T}: 1), \text { number } \\
\text { two }(\mathrm{T}: 2) \text {, second }(\mathrm{C}: 1), \text { for one thing }(\mathrm{T}: 1), \text { the other } \\
\text { thing }(\mathrm{C}: 1, \mathrm{~T}: 1), \text { third }(\mathrm{C}: 1) \text {, finally }(\mathrm{C}: 3)\end{array}$ \\
\hline & & concessive & though $(\mathrm{C}: 2)$, even if $(\mathrm{T}: 1)$ \\
\hline & & temporal & $\begin{array}{c}\text { when }(\mathrm{C}: 22, \mathrm{~T}: 43), \operatorname{now}(\mathrm{C}: 7, \mathrm{~T}: 15), \operatorname{after}(\mathrm{C}: 2, \mathrm{~T}: 2), \\
\text { before }(\mathrm{C}: 2, \mathrm{~T}: 6)\end{array}$ \\
\hline & & emphatic & $\begin{array}{c}\text { very }(\mathrm{C}: 12, \mathrm{~T}: 66), \text { really }(\mathrm{C}: 19, \mathrm{~T}: 17), \text { almost }(\mathrm{C}: 1, \\
\mathrm{T}: 11), \text { actually }(\mathrm{C}: 10, \mathrm{~T}: 4), \text { extremely }(\mathrm{T}: 2), \\
\text { totally }(\mathrm{T}: 4), \text { indeed }(\mathrm{C}: 1), \text { obviously }(\mathrm{C}: 1, \mathrm{~T}: 1), \\
\text { probably }(\mathrm{C}: 1, \mathrm{~T}: 4), \text { frankly }(\mathrm{T}: 3), \text { honestly }(\mathrm{T}: 1), \\
\text { basically }(\mathrm{C}: 2), \text { especially }(\mathrm{T}: 1), \text { absolutely }(\mathrm{C}: 3, \mathrm{~T}: 2), \\
\text { clearly }(\mathrm{C}: 2), \text { unbelievably }(\mathrm{T}: 1), \text { unfortunately }(\mathrm{C}: 3)\end{array}$ \\
\hline & & qualificatory & If(C:18, T:21), unless $(\mathrm{C}: 1)$ \\
\hline & & selective & Either/or(T:1) \\
\hline & & equivalent & $\begin{array}{l}\text { As well as }(\mathrm{C}: 1), \text { at the same time }(\mathrm{C}: 1, \mathrm{~T}: 1) \text {, or }(\mathrm{C}: 5 \text {, } \\
\mathrm{T}: 17)\end{array}$ \\
\hline & \multirow{2}{*}{$\begin{array}{l}\text { Filling } \\
\text { up } \\
\text { markers }\end{array}$} & $\begin{array}{c}\text { without explicit } \\
\text { meaning }\end{array}$ & $\begin{array}{c}\text { Well(C:31, T:15), oh(C:1), yeah(C:2, T:2), okay }(\mathrm{C}: 1), \\
u h(\mathrm{~T}: 1)\end{array}$ \\
\hline & & $\begin{array}{l}\text { with explicit } \\
\text { meaning }\end{array}$ & $\begin{array}{c}\text { I think }(\mathrm{C}: 33, \mathrm{~T}: 25), \text { you know }(\mathrm{C}: 12, \mathrm{~T}: 11), \text { you } \\
\text { see }(\mathrm{T}: 2), \text { I mean }(\mathrm{T}: 7), \text { look }(\mathrm{C}: 1, \mathrm{~T}: 6), \text { yes }(\mathrm{C}: 4, \mathrm{~T}: 2) \text {, } \\
\text { no }(\mathrm{C}: 4, \mathrm{~T}: 6) \text {, of course }(\mathrm{C}: 2, \mathrm{~T}: 1), \text { just say }(\mathrm{C}: 1)\end{array}$ \\
\hline
\end{tabular}

Note: C for Hillary Clinton, T for Donald Trump, numbers for frequency of specific DMs

In the debate, Clinton and Trump have to make efforts to make their statements clear enough to be understood and accepted by the audience, and thus they use DMs consciously or unconsciously to guide audiences to better understand their intentions with less processing effort. The following table illustrates additional and emphatic markers are the most common DMs used in the first presidential debate, ranking first and second, respectively.

Table 2. 14 types of DMs and their frequency in the first debate

\begin{tabular}{|l|l|l|}
\hline Type & Word number & Percentage \\
\hline additional & 204 & $19.50 \%$ \\
\hline emphatic & 172 & $16.44 \%$ \\
\hline causal and consequential & 119 & $11.38 \%$ \\
\hline contrastive & 118 & $11.28 \%$ \\
\hline with explicit meaning & 117 & $11.19 \%$ \\
\hline temporal & 99 & $9.46 \%$ \\
\hline repetitive & 64 & $6.12 \%$ \\
\hline without explicit meaning & 53 & $5.07 \%$ \\
\hline qualificatory & 40 & $3.82 \%$ \\
\hline equivalent & 25 & $2.39 \%$ \\
\hline sequential & 23 & $2.20 \%$ \\
\hline listing & 8 & $0.76 \%$ \\
\hline concessive & 3 & $0.29 \%$ \\
\hline selective & 1 & $0.096 \%$ \\
\hline
\end{tabular}

From the listener's perspective, he or she should infer what the speaker wants to describe by speaker's ostensive act with contextual assumption as a way to obtain contextual effect. (席建国, 2009: 163) In the debate, Clinton and Trump have to make efforts to make their statements clear 
enough to be understood and accepted by the audience, and thus they use DMs to guide audiences to better understand their intentions with less processing effort.

\subsubsection{Additional Markers}

Example 1:

Trump: And with a little leadership, you'd get it in here very quickly, and it could be put to use on the inner cities and lots of other things, and it would be beautiful.

Clinton: I have a feeling that by, the end of this evening, I'm going to be blamed for everything that's ever happened. (23:57-24:06)

Donald Trump is calling for tax cuts for the wealthiest Americans as he is convinced that those people are capable of creating jobs for Americans, but they would rather do businesses overseas due to onerous taxes in America, thereby the U. S. loses a great amount of money. In order to support his views, he uses additional markers "and" three times in a row. He uses the first and to show the following utterance is his idea that typical politicians like Clinton don't have any leadership to help America achieve prosperity. By the second and Trump would like to show he has leadership and under his tax-cut plan, the wealthiest Americans will bring large amount of money back into America, and he will make great use of it. The last and not only exudes his confidence, but also gives audiences a hint that life will be better if they choose him. The additional marker and here totally plays an ostensive role and Clinton's answer testifies that the usage of and has produced contextual effect.

Example 2:

Clinton: And we need to have smart, fair trade deals.

We also, though, need to have a tax system that rewards work and not just financial transactions. And the kind of plan that Donald has put forth would be trickle-down economics all over again. (06:59-07:11)

When Trump shows his stance about how to make more money for Americans, Clinton uses additional markers and and also to give a rebuttal. The first and is used to connect the foregoing statements about trade deals that Trump has mentioned. The marker also is a signal to audiences that the following statement is a supplement to the prior information. The second and serves as a supplement to her viewpoint about Trump's tax-cutting plan.

To sum up, both candidates prefer to use additional markers as it works to add some necessary and significant details of information in the course of presenting. By using additional markers, the speaker tells his/her audiences that what he/she is to utter are correlated with what has been mentioned and in consequence the audiences can understand the speaker effortlessly. In addition, frequent use of additional markers can enhance the speaker's aura to some extent, thus making speech less interruptible.

\subsubsection{Emphatic Markers}

Emphatic DMs can be employed by speaker to lay stress on the following statements. When the speaker believes that the utterance is significant, he or she may use emphatic DMs to raise audiences' attention in an effort to achieve his/her communicative intention.

Example 3:

Clinton: Mental health is one of the biggest concerns, because now police are having to handle a lot of really difficult mental health problems on the street. (50:49-50:55)

When questioned about how to improve policing to go right at implicit bias, Clinton proposes to put more fund into it to support and train those police officers who have to tackle mental health issues on the street. Although dealing with mental health issues is essential to addressing implicit bias, it is tough for police officer to handle difficult ones on the street. The DM really emphasizes the mental health issues are difficult to deal with. Thus, audiences may deem that her plan to inject money into training police officers makes sense.

Example 4:

Trump: Well, I'm really calling for major jobs... (22:33-22:37) 
Job is a subject that is the electorate's main concern, and the DM really could draw audiences' attention to his following statement and he employs really to emphasize he will be determined to create more jobs for them.

In a word, using emphatic DMs could help the speaker to emphasize his or her utterance and also attracts audiences' attention.

\section{Summary}

DMs, as a sort of crucial linguistic skill take up a large quantity of the debate, additional and emphatic markers in particular. Both candidates capitalize on DMs to make their statements clearly so as to achieve contextual effect. Therefore, in the daily communication and English debates, speakers could also make use of DMs to state their ideas to achieve their communicative goal.

In summary, by using complete sequential markers, speakers are able to express ideas logically and coherently, and, as a result, audiences could get the main points effortlessly; by using well, speakers can seize a moment to sort out their mind and prepare their statements carefully, giving audience a hint that they are going to make a response; by using relatively colloquial additional makers such as by the way to catch audiences' attention.

\section{References}

[1] Bruce Fraser, What are Discourse Markers?, Journal of Pragmatics, vol.7, pp. 931-952, 1999.

[2] D. Blakemore, Relevance and Linguistic Meaning: The Senantics and Pragmatics of Discourse Markers, Cambridge: Cambridge University, 2002.

[3] D. Schiffrin, Discourse Markers, Cambridge: Cambridge University Press, 1987.

[4] Keran Wu, A Pragmatic View on Discourse Markers in Presidential Debate, Tianjin: Tianjin University, 2010.

[5] Lina Shi, Pragmatic Study of Discourse Markers in the U.S. Presidential Debates, Xian: Xi'an Technological University, 2013.

[6] Xinyue Chang, A Pragmatic Analysis of Discourse Markers in the 2008 U.S. Presidential Debate, Changchun: Northeast Normal University, 2009.

[7] Xinyue Chang, A Pragmatic Analysis of Discourse Markers in the 2008 U.S. Presidential Debate, Changchun: Northeast Normal University, 2009.

[8] Yongping Ran, A Review of Discourse Markers in Pragmatics, Foreign Languages Research, vol.4, pp. 8-14, 2000.

[9] Ziran He, and Yongping Ran, Cognitive Pragmatics: Cognition in Verbal Communication, Shanghai: Shanghai Foreign Language Education Press, 2006. 